\title{
Variations of net primary productivity and phytoplankton community composition in the Indian sector of the Southern Ocean as estimated from ocean color remote sensing data
}

\author{
S. Takao ${ }^{1}$, T. Hirawake ${ }^{2}$, S. W. Wright ${ }^{3,4}$, and K. Suzuki ${ }^{1,5,6}$ \\ ${ }^{1}$ Graduate School of Environmental Science, Hokkaido University, North 10 West 5, Kita-ku, Sapporo, Hokkaido 060-0810, \\ Japan \\ ${ }^{2}$ Faculty of Fisheries Sciences, Hokkaido University, 3-1-1 Minato-cho, Hakodate, Hokkaido 041-8611, Japan \\ ${ }^{3}$ Australian Antarctic Division, 203 Channel Highway, Kingston, Tasmania 7050, Australia \\ ${ }^{4}$ Antarctic Climate and Ecosystems Cooperative Research Centre, University of Tasmania, Private Bag 80, Hobart, Tasmania \\ 7001, Australia \\ ${ }^{5}$ Faculty of Environmental Earth Science, Hokkaido University, North 10 West 5, Kita-ku, Sapporo, Hokkaido 060-0810, \\ Japan \\ ${ }^{6}$ CREST, Japan Science and Technology Agency, North 10 West 5, Kita-ku, Sapporo, Hokkaido 060-0810, Japan \\ Correspondence to: S. Takao (takao@ees.hokudai.ac.jp)
}

Received: 23 March 2012 - Published in Biogeosciences Discuss.: 12 April 2012

Revised: 11 September 2012 - Accepted: 12 September 2012 - Published: 9 October 2012

\begin{abstract}
Phytoplankton population dynamics play an important role in biogeochemical cycles in the Southern Ocean during austral summer. Recent environmental changes such as a rise in sea surface temperature (SST) are likely to impact on net primary productivity (NPP) and phytoplankton community composition. However, their spatiotemporal relationships are still unclear in the Southern Ocean. Here we assessed the relationships between NPP, dominant phytoplankton groups, and SST in the Indian sector of the Southern Ocean over the past decade (1997-2007) using satellite remote sensing data. As a result, we found a statistically significant reduction in NPP in the polar frontal zone over the past decade during austral summer. Moreover, the decrease in NPP positively correlated with the dominance of diatoms (Kendall's rank correlation $\tau=0.60$ ) estimated by a phytoplankton community composition model, but not correlated with SST. In the seasonal ice zone, NPP correlated with not only the dominance of diatoms positively $(\tau=0.56)$, but also the dominance of haptophytes $(\tau=-0.54)$ and SST $(\tau=-0.54)$ negatively. Our results suggested that summer NPP values were strongly affected by the phytoplankton community composition in the Indian sector of the Southern Ocean.
\end{abstract}

\section{Introduction}

The Southern Ocean represents approximately $20 \%$ of the world's surface ocean area (Tomczak and Godfrey, 2003) and is a large sink of atmospheric carbon dioxide $\left(\mathrm{CO}_{2}\right)$ at the rate of ca. $1.5 \times 10^{15} \mathrm{~g} \mathrm{C} \mathrm{yr}^{-1}$ (McNeil et al., 2007). This region also has unique circulation features. For example, the Antarctic Circumpolar Current (ACC), driven by strong westerly winds between 45 and $55^{\circ} \mathrm{S}$, flows through the Atlantic, Indian and Pacific Oceans without continental barrier (Nowlin and Klinck, 1986; Trenberth et al., 1990). The interoceanic connection driven by the ACC facilitates the global transport of heat and materials that influence global climate and ecosystems (Gordon, 2001; Sarmiento et al., 2004). The ACC is also associated with several oceanic fronts: the Subtropical Front (STF), Subantarctic Front (SAF), Polar Front (PF) and the Southern Boundary (SB) of the ACC (Orsi et al., 1995; Belkin and Gordon, 1996). These frontal regions are characterized by sharp horizontal gradients in hydrographic properties that represent the boundaries of distinct water masses (Orsi et al., 1995; Belkin and Gordon, 1996; Rintoul and Bullister, 1999; Sokolov and Rintoul, 2002; Longhurst, 2006). 


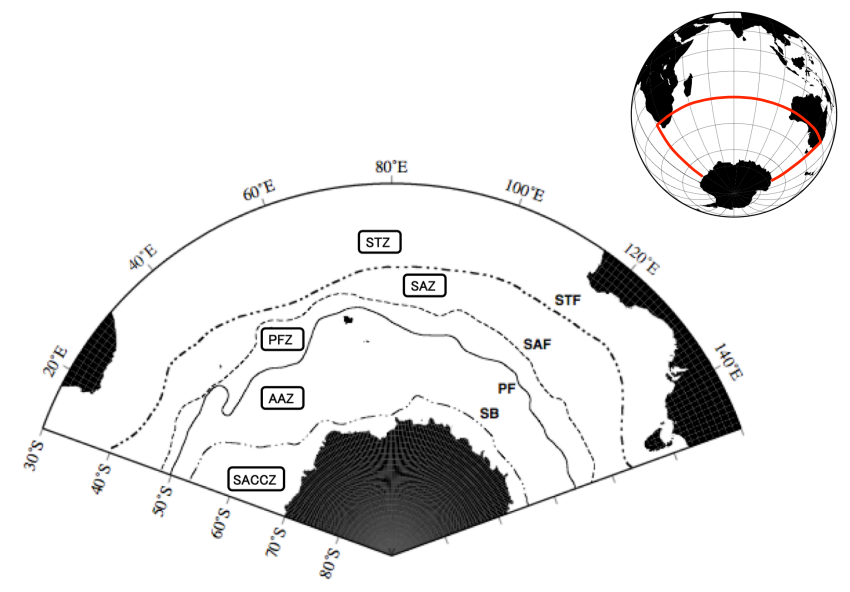

Fig. 1. Climatological locations of the four fronts and five frontal zones. STF, Subtropical Front; SAF, Subantarctic Front; PF, Polar Front; SB, Southern Boundary; STZ, Subtropical Frontal Zone; SAZ, Subantarctic Frontal Zone; PFZ, Polar Frontal Zone; AAZ, Antarctic Zone; SACCZ, zone south of the ACC (Antarctic Circumpolar Current).

Although the Southern Ocean is known as one of the largest high-nutrient, low-chlorophyll (HNLC) regions where iron availability can control algal stocks and productivity (Martin et al., 1990; Coale et al., 2004), phytoplankton blooms sometimes occur in several regions including the areas associated with sea ice retreat, strong upwelling, and high eddy kinetic energy driven by the ACC fronts (Comiso et al., 1993; Moore and Abbott, 2000). In particular, during austral summer, phytoplankton productivity plays a crucial role in the carbon cycle of the Southern Ocean (Takahashi et al., 2002). It is known that efficiency of the biological carbon pump strongly depends on the phytoplankton community composition. Large diatoms are thought to be superior to other phytoplankton groups for the transport of particulate organic carbon from the surface to the deeper layers due to their heavy silica frustules (Tréguer and Pondaven, 2000). Precipitation of $\mathrm{CaCO}_{3}$ in coccolithophores increases the partial pressure of $\mathrm{CO}_{2}$ in seawater (Frankignoulle et al., 1994), while the carbonate production has also a large effect on increasing sinking velocities and thus particle export to the ocean interior (Buitenhuis et al., 2001). On the other hand, the non-calcifying haptophyte Phaeocystis antarctica regularly forms huge colonies in seasonal ice zones and coastal Antarctic waters, and possesses high sinking rates, resulting in a significant carbon export from surface waters (DiTullio et al., 2000).

Recent climate changes could impact net primary productivity (NPP) through changes in environmental conditions such as sea surface temperature (SST), nutrient availability, and water column stratification (Behrenfeld et al., 2006; Doney, 2006). These shifts are also likely to affect the phytoplankton community composition. For instance, in coastal waters along the western shelf of Antarctic Peninsula (WAP), a greater dominance of cryptophytes over diatoms has been hypothesized as a response to the regional warming (Moline et al., 2004). Montes-Hugo et al. (2009) also found a significant change in chlorophyll (chl) $a$ concentration between 1978-1986 and 1998-2006 periods along the WAP by using satellite and field data. This change could be accompanied by changes in the community composition of phytoplankton.

In the Indian sector of the Southern Ocean, many studies have examined spatiotemporal variability of primary productivity and phytoplankton community composition (e.g., Strutton et al., 2000; Westwood et al., 2010; Wright and van den Enden, 2000; Wright et al., 2010), yet the large-scale geographic and long-term temporal variability remains unclear. Owing to the recent development of satellite ocean color remote sensing, spatiotemporal variations of NPP (e.g., Behrenfeld and Falkowski, 1997) and specific phytoplankton taxonomic or functional groups (e.g., Alvain et al., 2005, 2008; Hirata et al., 2011) can be estimated on a global scale. A few studies have examined spatiotemporal trends of NPP in the Southern Ocean using satellite-based methods (Arrigo et al., 2008; Smith and Comiso, 2008; Johnston and Gabric, 2011). However, no study has assessed the relationships between NPP and phytoplankton taxonomic groups in the Southern Ocean for long periods. Our goal here is to assess the relationships between NPP, dominant phytoplankton groups, and SST in the Indian sector of the Southern Ocean over the past decade (1997-2007) using satellite remote sensing data.

\section{Materials and methods}

\subsection{Satellite data processing}

The satellite dataset used in this study were normalized water leaving radiance $\left(L_{\mathrm{wn}}\right)$, chl $a$ concentration $\left(\mathrm{chl}_{\mathrm{sat}}\right)$, the aerosol optical thickness at $865 \mathrm{~nm}$ (AOT), photosynthetically available radiation (PAR) from the Sea-viewing Wide Field-of-view Sensor (SeaWiFS), and SST from Advanced Very High Resolution Radiometer (AVHRR). SeaWiFS monthly data $(9 \mathrm{~km}$ resolution) for the period from September 1997 to August 2007 were obtained from the Distributed Active Archive Center (DAAC)/Goddard Space Flight Center (GSFC), NASA. Daily data ( $9 \mathrm{~km}$ resolution) was also used for validation of a phytoplankton community composition model (see Sect. 2.2.1). Monthly data of daytime SST ( $4 \mathrm{~km}$ resolution) were resampled to match the resolution of SeaWiFS data. Satellite data were analyzed for five frontal zones within the Indian sector of the Southern Ocean. Figure 1 shows climatological locations of the four fronts and five frontal zones determined by Orsi et al. (1995) and Pollard et al. (2002), respectively.

An absorption-based model for estimating daily net primary productivity (Hirawake et al., 2011) was employed in 
this study. This model was developed on the basis of the Vertically Generalized Production Model (VGPM) proposed by Behrenfeld and Falkowski (1997), and the product of the maximum primary productivity per unit of chl $a$ within the water-column $\left(P_{\mathrm{opt}}^{\mathrm{B}}\right)$ and chl $a$ was estimated from phytoplankton absorption coefficients. Daily net primary productivity (NPP, $\mathrm{mg} \mathrm{C} \mathrm{m}^{-2} \mathrm{~d}^{-1}$ ) integrated over the upper euphotic depth is calculated as

$\mathrm{NPP}=\left[109.66 \bar{a}_{\phi}(0-)-0.02\right] \times \frac{0.66125 \times E_{0}}{E_{0}+4.1} \times Z_{\mathrm{eu}} \times \mathrm{DL}$,

where $\bar{a}_{\phi}(0-)$ is the spectrally averaged absorption coefficient of phytoplankton over $400-700 \mathrm{~nm}$ at just blow the sea surface, $E_{0}$ is daily sea surface PAR, $Z_{\mathrm{eu}}$ is euphotic depth, and "DL" is day length. Sea surface $a_{\phi}(\lambda)$ was estimated using the quasi-analytical algorithm (QAA) (Lee et al., 2002) and $\bar{a}_{\phi}$ was calculated from $a_{\phi}(\lambda)$ at five SeaWiFS bands (i.e., $\lambda=412,443,490,510$ and $555 \mathrm{~nm}$ ) (Hirawake et al., 2011). $Z_{\mathrm{eu}}$ was estimated using QAA derived absorption and backscattering coefficients according to Lee et al. (2007). DL was calculated as a function of latitude and time of year (Brock, 1981). Hirawake et al. (2011) showed a better agreement between in situ and estimated NPP using the absorption based model $\left(r^{2}=0.80\right.$, slope $\left.=1.11 \pm 0.21\right)$ compared with the VGPM $\left(r^{2}=0.19\right.$, slope $\left.=0.24 \pm 0.18\right)$ in the Indian sector of the Southern Ocean (see Appendix A for more details).

Phytoplankton community composition was determined following the algorithm PHYSAT (Alvain et al., 2005), which allowed us to estimate the spatiotemporal distributions of the four Phytoplankton Functional Types (PFTs), that is, haptophytes, Prochlorococcus, Synechococcus, and diatoms, from SeaWiFS $\mathrm{chl}_{\text {sat }}$ ranging between $0.04-3 \mathrm{mg} \mathrm{m}^{-3}$ and AOT lower than 0.15 . This classification relies on specific normalized water-leaving radiance $\left(L_{\mathrm{wn}}^{*}\right)$ spectra defined as

$L_{\mathrm{wn}}^{*}(\lambda)=L_{\mathrm{wn}}(\lambda) / L_{\mathrm{wn}}^{\mathrm{ref}}\left(\lambda, \operatorname{chl}_{\mathrm{sat}}\right)$,

where $L_{\mathrm{wn}}^{\mathrm{ref}}$ is a mean $L_{\mathrm{wn}}$ model that depends only on chl $\mathrm{sat}_{\mathrm{sa}}$, and $\lambda$ is wavelength based on the five SeaWiFS bands. However, direct comparisons of the PHYSAT results with NPP or SST values are difficult because of the limitation of PHYSAT (i.e., it only determines which PFTs are dominant). To overcome this problem, in each frontal zone, we defined the dominant ratio (DR) for PFTs as follows:

$\mathrm{DR}_{\mathrm{i}}=\frac{P_{\mathrm{i}}}{P_{\mathrm{PFTs}}} \times 100$,

where "i" indicates index for each PFT (in order, haptophytes, Prochlorococcus, Synechococcus and diatoms), $P_{\mathrm{i}}$ is the number of pixels where PFT (i) dominates, and $P_{\mathrm{PFTs}}$ is the sum of the number of pixels where PFTs dominated.

In order to obtain seasonal data, monthly NPP and SST values were averaged by the following every three months on a pixel-by-pixel basis: September-November for austral spring, December-February for austral summer, March-May for austral autumn, and June-August for austral winter. For phytoplankton community composition, monthly distributions and DR values for each PFT were estimated, and thereafter the seasonal DR data of each PFT were averaged every three months.

\subsection{Validations of satellite-derived phytoplankton com- position by HPLC pigment analysis and light mi- croscopy}

In situ phytoplankton pigment and algal species data measured with high-performance liquid chromatography (HPLC) and light microscopy, respectively, were matched up with daily SeaWiFS data in order to validate the results of the PHYSAT performance in our study area. The phytoplankton pigment data were obtained from four TR/V UmitakaMaru cruises (Tokyo University of Marine Science and Technology) in the austral summer of 2004/2005, 2005/2006, 2007/2008 and 2008/2009 and the Baseline Research on Oceanography, Krill and the Environment-West (BROKEWest) cruise (Wright et al., 2010). Samples for light microscopy were acquired from the 2004/2005 Umitaka-Maru cruise $(n=14)$. The HPLC pigment and microscope samples were collected with Teflon-coated Niskin bottles attached to CTD systems (Falmouth Scientific Inc. or Sea-Bird Electric, Inc.) or a Teflon-coated bucket.

\subsubsection{Phytoplankton pigment analysis}

Seawater samples (0.5-71) collected during Umitaka-Maru and BROKE-West cruises were filtered onto $25 \mathrm{~mm}$ and $13 \mathrm{~mm}$ Whatman GF/F glass fibers, respectively. The GF/F filters were blotted and stored in liquid nitrogen or a deepfreezer $\left(-80^{\circ} \mathrm{C}\right)$ until analysis on land. Analytical procedures of phytoplankton pigments in the Umitaka-Maru and BROKE-West samples were detailed in Hashihama et al. (2008) and Wright et al. (2010), respectively. In this study, near surface pigment data (taken from depths between 0 and $15 \mathrm{~m}$ ) were interpreted by the matrix factorization program CHEMTAX (Mackey et al., 1996) to estimate the contributions of each algal class to the total chl $a$ biomass determined by HPLC. For the CHEMTAX calculations, 314 pigment data were categorized into the four groups (i.e., group A, B, C and D) based on the cluster analysis (see Appendix B) and then treated separately following the method of Latasa (2007) with several seed values. The accessory pigment to chl $a$ ratios in Table 1 are based on the initial pigment ratios of Wright et al. (1996). In this study, a dominant phytoplankton group was defined as having $>50 \%$ contributions to chl $a$ biomass. The final CHEMTAX outputs were compared to the results of the PHYSAT within \pm 1 pixel (i.e., $9 \mathrm{~km})$ and \pm 2 days. In the NASA's definition for data and algorithm validation (Bailey and Werdell, 2006), only data on 
Table 1. CHEMTAX analysis of accessory pigment to chl $a$ ratios in the major algal classes: (a) initial ratios; (b) final ratios. Perid, peridinin; 19butfu, 19'-butanoyloxyfucoxanthin; Fucox, fucoxanthin; 19hexfu, 19'-hexanoyloxyfucoxanthin; Allox, alloxanthin; Chl $b$, chlorophyll $b$; Chl $a$, chlorophyll $a$. Groups A-D represent categories based on the cluster analysis using pigment data. Note: The common name "Green algae" includes Chlorophyceae and Prasinophyceae and possibly Euglenophyceae.

\begin{tabular}{|c|c|c|c|c|c|c|c|}
\hline & Perid & 19butfu & Fucox & 19hexfu & Allox & Chl $b$ & Chl $a$ \\
\hline \multicolumn{8}{|l|}{$\begin{array}{l}\text { (a) Initial ratios } \\
\text { (Group A) }\end{array}$} \\
\hline Dinoflagellates & 1.42 & 0 & 0 & 0 & - & 0 & 1 \\
\hline Haptophytes6 & 0 & 0.017 & 0.093 & 0.74 & - & 0 & 1 \\
\hline Haptophytes8 & 0 & 0.32 & 1.14 & 0.84 & - & 0 & 1 \\
\hline Green algae & 0 & 0 & 0 & 0 & - & 0.24 & 1 \\
\hline Diatoms & 0 & 0 & 1.20 & 0 & - & 0 & 1 \\
\hline \multicolumn{8}{|l|}{ (Group B) } \\
\hline Dinoflagellates & 1.12 & 0 & 0 & 0 & - & 0 & 1 \\
\hline Haptophytes6 & 0 & 0.037 & 0.14 & 1.21 & - & 0 & 1 \\
\hline Haptophytes8 & 0 & 0.12 & 0.38 & 0.56 & - & 0 & 1 \\
\hline Green algae & 0 & 0 & 0 & 0 & - & 0.38 & 1 \\
\hline Diatoms & 0 & 0 & 0.77 & 0 & - & 0 & 1 \\
\hline \multicolumn{8}{|l|}{ (Group C) } \\
\hline Dinoflagellates & 1.12 & 0 & 0 & 0 & 0 & 0 & 1 \\
\hline Cryptophytes & 0 & 0 & 0 & 0 & 0.080 & 0 & 1 \\
\hline Haptophytes6 & 0 & 0.059 & 0.25 & 2.04 & 0 & 0 & 1 \\
\hline Haptophytes8 & 0 & 0.30 & 0.65 & 0.89 & 0 & 0 & 1 \\
\hline Green algae & 0 & 0 & 0 & 0 & 0 & 0.30 & 1 \\
\hline Diatoms & 0 & 0 & 1.58 & 0 & 0 & 0 & 1 \\
\hline \multicolumn{8}{|l|}{ (Group D) } \\
\hline Dinoflagellates & 0.91 & 0 & 0 & 0 & - & - & 1 \\
\hline Haptophytes6 & 0 & 0.055 & 0.27 & 2.26 & - & - & 1 \\
\hline Haptophytes8 & 0 & 0.23 & 0.32 & 0.33 & - & - & 1 \\
\hline Diatoms & 0 & 0 & 1.07 & 0 & - & - & 1 \\
\hline \multicolumn{8}{|l|}{$\begin{array}{l}\text { (b) Final ratios } \\
\text { (Group A) }\end{array}$} \\
\hline Dinoflagellates & 1.48 & 0 & 0 & 0 & - & 0 & 1 \\
\hline Haptophytes6 & 0 & 0.016 & 0.086 & 0.68 & - & 0 & 1 \\
\hline Haptophytes8 & 0 & 0.39 & 1.55 & 1.15 & - & 0 & 1 \\
\hline Green algae & 0 & 0 & 0 & 0 & - & 0.16 & 1 \\
\hline Diatoms & 0 & 0 & 1.23 & 0 & - & 0 & 1 \\
\hline \multicolumn{8}{|l|}{ (Group B) } \\
\hline Dinoflagellates & 1.12 & 0 & 0 & 0 & - & 0 & 1 \\
\hline Haptophytes6 & 0 & 0.037 & 0.14 & 1.21 & - & 0 & 1 \\
\hline Haptophytes8 & 0 & 0.13 & 0.34 & 0.56 & - & 0 & 1 \\
\hline Green algae & 0 & 0 & 0 & 0 & - & 0.45 & 1 \\
\hline Diatoms & 0 & 0 & 0.77 & 0 & - & 0 & 1 \\
\hline \multicolumn{8}{|l|}{ (Group C) } \\
\hline Dinoflagellates & 1.12 & 0 & 0 & 0 & 0 & 0 & 1 \\
\hline Cryptophytes & 0 & 0 & 0 & 0 & 0.080 & 0 & 1 \\
\hline Haptophytes6 & 0 & 0.059 & 0.25 & 2.35 & 0 & 0 & 1 \\
\hline Haptophytes8 & 0 & 0.40 & 0.86 & 1.18 & 0 & 0 & 1 \\
\hline Green algae & 0 & 0 & 0 & 0 & 0 & 0.30 & 1 \\
\hline Diatoms & 0 & 0 & 1.58 & 0 & 0 & 0 & 1 \\
\hline \multicolumn{8}{|l|}{ (Group D) } \\
\hline Dinoflagellates & 0.77 & 0 & 0 & 0 & - & - & 1 \\
\hline Haptophytes6 & 0 & 0.040 & 0.20 & 1.66 & - & - & 1 \\
\hline Haptophytes8 & 0 & 0.19 & 0.27 & 0.28 & - & - & 1 \\
\hline Diatoms & 0 & 0 & 0.88 & 0 & - & - & 1 \\
\hline
\end{tabular}


the same date (i.e., Day 0) is used for the matchup. However, using such a definition, only 4 coincident data points were available to validate PHYSAT in our study. Thus, to increase the number of coincident SeaWiFS data, the time window was extended to \pm 2 days.

\subsubsection{Light microscopy}

The water samples $(500 \mathrm{ml})$ collected from the sea surface was preserved with $4 \%$ Lugol's iodine solution. Phytoplankton cells were identified following Tomas (1997) and counted. Cell volumes were calculated for each species by applying cellular dimensions to the formulae for solid geometric shapes most closely matching the shapes of the cells (Hillebrand et al., 1999). Since phytoplankton cells including diatoms shrink due to fixation with Lugol's iodine solution, the cell volumes of fixed samples were corrected using the formula proposed by Montagnes et al. (1994). Furthermore, the carbon biomasses of each algal group were estimated using the empirical equations of Strathmann (1967) and the cell volumes, and the data obtained were compared to the final CHEMTAX outputs. Although some phytoplankton species other than diatoms and dinoflagellates were also identified by light microscopy, their quantitative data analyses were omitted due to their relatively low abundances compared to diatoms and dinoflagellates in the present study.

\subsection{Statistical analyses}

Correlations are computed between NPP, dominant phytoplankton groups and SST using Kendall's rank correlation $(\tau)$. Then seasonal mean values of the parameters in five frontal zones over the 10 years from 1997 to 2007 were used. Trends and their significance in the time series are estimated using the non-parametric Sen's slope and the Mann-Kendall test. Trends at $95 \%$ confidence level are reported here as significant. It should be noted that, in the Polar Frontal Zone (PFZ), the Antarctic Zone (AAZ) and the zone south of the Antarctic Circumpolar Current (SACCZ), the cyanobacteria Prochlorococcus and Synechococcus were excluded from the correlation tests, because the two genera are very low abundances in areas south of $50^{\circ} \mathrm{S}$ (Marchant et al., 1987; Odate and Fukuchi, 1995; Zubkov et al., 1998; Fouilland et al., 1999).

\section{Results}

\subsection{Net primary productivity}

\subsubsection{Spatial and seasonal variations}

The seasonal mean values of NPP over the past decade (1997-2007) showed significant spatial variability in our study area (Fig. 2). Enhanced NPP values (250-400 mg C $\left.\mathrm{m}^{-2} \mathrm{~d}^{-1}\right)$ were observed between the STF and PF $\left(35-55^{\circ} \mathrm{S}\right)$
Table 2. Inter-annual variations in seasonal mean NPP (mg C $\mathrm{m}^{-2} \mathrm{~d}^{-1}$ ) in the five frontal zones from 1997 to 2007 during austral spring, summer, autumn and winter.

\begin{tabular}{|c|c|c|c|c|c|c|}
\hline Year & STZ & SAZ & PFZ & AAZ & SACCZ & Total \\
\hline \multicolumn{7}{|c|}{ Spring } \\
\hline 1997 & 189 & 195 & 134 & 132 & - & 167 \\
\hline 1998 & 189 & 176 & 154 & 144 & - & 169 \\
\hline 1999 & 177 & 175 & 148 & 149 & - & 164 \\
\hline 2000 & 172 & 171 & 127 & 106 & - & 148 \\
\hline 2001 & 167 & 172 & 147 & 138 & - & 157 \\
\hline 2002 & 185 & 184 & 144 & 110 & - & 159 \\
\hline 2003 & 183 & 172 & 162 & 130 & - & 164 \\
\hline 2004 & 174 & 192 & 165 & 134 & - & 166 \\
\hline 2005 & 184 & 177 & 142 & 124 & - & 162 \\
\hline 2006 & 181 & 191 & 152 & 121 & - & 163 \\
\hline Mean & 180 & 180 & 147 & 129 & - & 162 \\
\hline SD & 7 & 9 & 12 & 14 & - & 6 \\
\hline \multicolumn{7}{|c|}{ Summer } \\
\hline 1997-1998 & 167 & 280 & 202 & 194 & 180 & 202 \\
\hline 1998-1999 & 165 & 266 & 213 & 208 & 369 & 225 \\
\hline 1999-2000 & 155 & 267 & 204 & 250 & 388 & 235 \\
\hline 2000-2001 & 163 & 277 & 197 & 192 & 216 & 203 \\
\hline 2001-2002 & 145 & 240 & 197 & 177 & 235 & 188 \\
\hline 2002-2003 & 178 & 282 & 197 & 169 & 279 & 209 \\
\hline 2003-2004 & 169 & 285 & 201 & 173 & 384 & 220 \\
\hline 2004-2005 & 165 & 260 & 183 & 171 & 296 & 201 \\
\hline 2005-2006 & 177 & 259 & 178 & 172 & 332 & 209 \\
\hline 2006-2007 & 158 & 240 & 185 & 201 & 341 & 209 \\
\hline Mean & 164 & 266 & 196 & 191 & 302 & 210 \\
\hline SD & 10 & 16 & 11 & 25 & 73 & 14 \\
\hline \multicolumn{7}{|c|}{ Autumn } \\
\hline 1998 & 129 & 151 & 80 & 56 & 84 & 103 \\
\hline 1999 & 125 & 150 & 83 & 80 & 101 & 110 \\
\hline 2000 & 118 & 147 & 88 & 74 & 123 & 109 \\
\hline 2001 & 126 & 156 & 86 & 70 & 82 & 107 \\
\hline 2002 & 124 & 153 & 80 & 58 & 84 & 103 \\
\hline 2003 & 130 & 153 & 73 & 57 & 92 & 103 \\
\hline 2004 & 126 & 144 & 70 & 53 & 128 & 103 \\
\hline 2005 & 124 & 136 & 69 & 63 & 103 & 101 \\
\hline 2006 & 131 & 132 & 77 & 61 & 115 & 104 \\
\hline 2007 & 129 & 154 & 84 & 70 & 117 & 111 \\
\hline Mean & 126 & 148 & 79 & 64 & 103 & 105 \\
\hline SD & 4 & 8 & 7 & 9 & 17 & 4 \\
\hline \multicolumn{7}{|c|}{ Winter } \\
\hline 1998 & 98 & 61 & 41 & - & - & 71 \\
\hline 1999 & 95 & 57 & 39 & - & - & 67 \\
\hline 2000 & 98 & 60 & 36 & - & - & 68 \\
\hline 2001 & 103 & 66 & 45 & - & - & 73 \\
\hline 2002 & 94 & 57 & 45 & - & - & 68 \\
\hline 2003 & 92 & 53 & 38 & - & - & 65 \\
\hline 2004 & 96 & 54 & 32 & - & - & 66 \\
\hline 2005 & 91 & 53 & 30 & - & - & 62 \\
\hline 2006 & 101 & 56 & 39 & - & - & 70 \\
\hline 2007 & 99 & 62 & 45 & - & - & 72 \\
\hline Mean & 97 & 58 & 39 & - & - & 68 \\
\hline SD & 4 & 4 & 5 & - & - & 3 \\
\hline
\end{tabular}



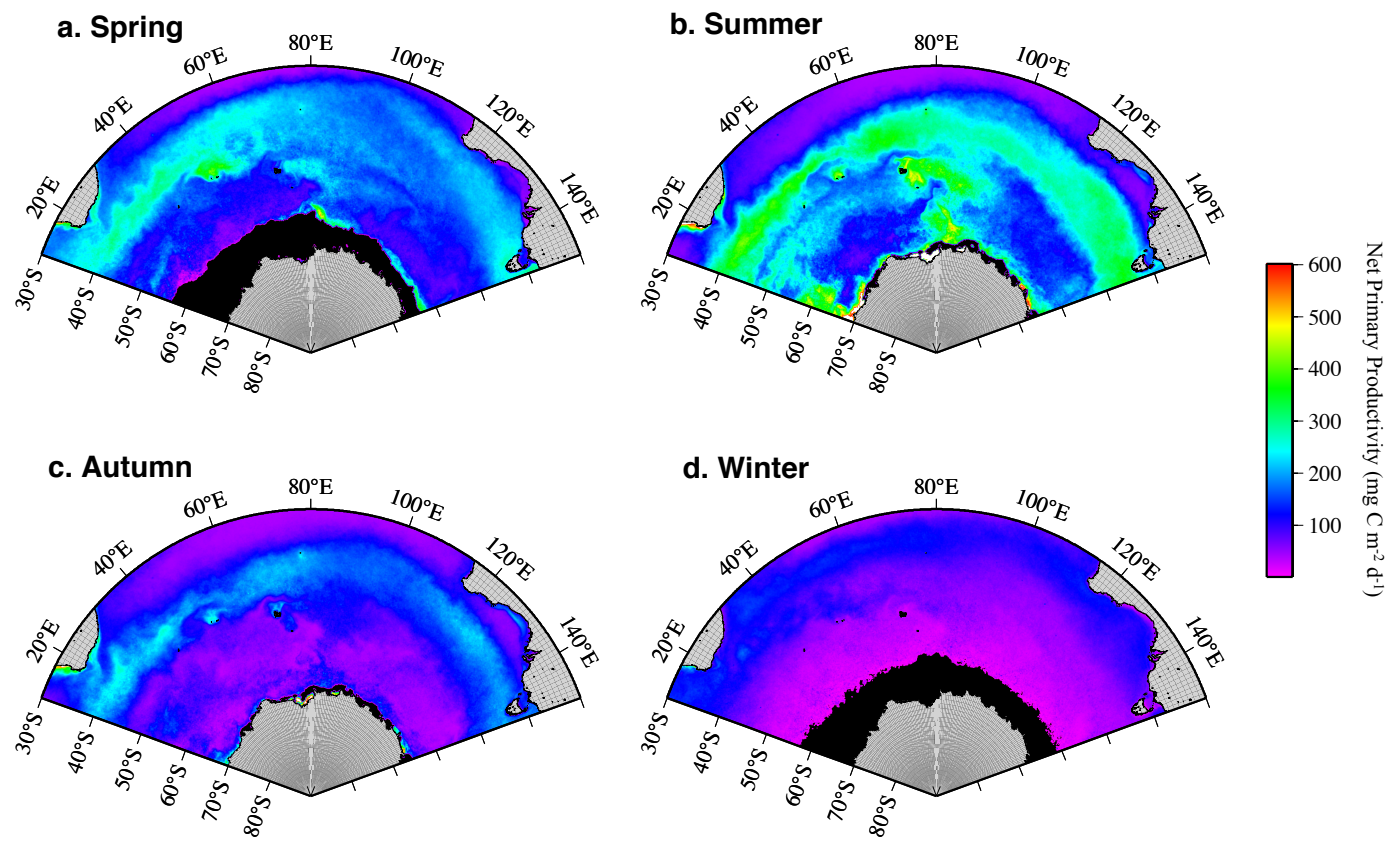

Fig. 2. Seasonal mean values of net primary productivity $\left(\mathrm{mg} \mathrm{C} \mathrm{m}^{-2} \mathrm{~d}^{-1}\right)$ in the Indian sector of the Southern Ocean from 1997 to 2007 during (a) austral spring (September-November), (b) summer (December-February), (c) autumn (March-May) and (d) winter (June-August). Areas in black represent no satellite data due to cloudiness or sea ice cover.

during austral spring to autumn, and the area extended from west to east toward summer (Fig. 2a to c). Although sea ice still existed during austral spring, relatively high values of NPP ( $>400 \mathrm{mg} \mathrm{C} \mathrm{m}^{-2} \mathrm{~d}^{-1}$ ) were observed near the receding ice edge on the Kerguelen plateau $\left(>50^{\circ} \mathrm{S}, 70-90^{\circ} \mathrm{E}\right)$ and in the Australian sector $\left(110-150^{\circ} \mathrm{E}\right)$ (Fig. 2a). The highest NPP occurred during austral summer, with $>500 \mathrm{mg} \mathrm{C}$ $\mathrm{m}^{-2} \mathrm{~d}^{-1}$ around the Antarctic coastal areas (Fig. 2b). Elevated NPP was also found in the vicinity of the major fronts (STF, SAF and PF), associated with ice retreat, the Kerguelen plateau, and the east end of Weddell Gyre (55$70^{\circ} \mathrm{S}, 0-20^{\circ} \mathrm{E}$ ). Higher productivity still remained around the Antarctic coastal areas during austral autumn (Fig. 2c). During austral winter, NPP was relative low $(<150 \mathrm{mg} \mathrm{C}$ $\mathrm{m}^{-2} \mathrm{~d}^{-1}$ ) compared with other seasons because of low irradiance caused by the high solar zenith angle over the Southern Ocean, especially south of the PF (Fig. 2d).

\subsubsection{Inter-annual variations}

Inter-annual variations of seasonal mean NPP in five frontal zones over the past decade were examined, and the results are listed in Table 2. However, it should be noted that some frontal zones were excluded from the analyses, because fewer than $60 \%$ of the total pixels were available (mainly due to sea ice cover). In austral spring, the AAZ had greatest inter-annual variations of the spatial averaged NPP of the five frontal zones, ranging from $106 \mathrm{~m} \mathrm{C} \mathrm{m}^{-2} \mathrm{~d}^{-1}$ in 2000 to $149 \mathrm{mg} \mathrm{C} \mathrm{m}^{-2} \mathrm{~d}^{-1}$ in 1999 . During summer to autumn,
Table 3. Annual trends $\left(\mathrm{mg} \mathrm{C} \mathrm{m}^{-2} \mathrm{~d}^{-1} \mathrm{yr}^{-1}\right)$ for the seasonal mean NPP in the five frontal zones over 1997-2007.

\begin{tabular}{lrrrrr}
\hline Season & STZ & SAZ & PFZ & AAZ & SACCZ \\
\hline Spring & -0.76 & 0.42 & 1.78 & -2.82 & - \\
Summer & 0.23 & -1.58 & $-\mathbf{2 . 9 1}$ & -3.29 & 16.60 \\
Autumn & 0.40 & -1.24 & -1.38 & -0.80 & 3.72 \\
Winter & -0.20 & -0.62 & -0.23 & - & - \\
\hline
\end{tabular}

Bold numbers denote statistical significance at the $95 \%$ confidence level. In all cases, number of samples is 10 .

inter-annual variations in NPP were greatest in the SACCZ, where seasonal sea ice cover exists, and ranged from $180 \mathrm{mg}$ $\mathrm{C} \mathrm{m}^{-2} \mathrm{~d}^{-1}$ during $1997-1998$ to $388 \mathrm{mg} \mathrm{C} \mathrm{m}^{-2} \mathrm{~d}^{-1}$ during 1999-2000. The difference between the highest and lowest values exceeded $100 \mathrm{Tg} C$ per season over the entire SACCZ. The SACCZ also had the greatest range of NPP in autumn, from $82 \mathrm{mg} \mathrm{C} \mathrm{m}^{-2} \mathrm{~d}^{-1}$ in 2001 to $128 \mathrm{mg} \mathrm{C} \mathrm{m}^{-2} \mathrm{~d}^{-1}$ in 2004. In winter, inter-annual variations of the spatial averaged NPP were greatest in the PFZ, although the difference between the highest and lowest values was only $15 \mathrm{mg} \mathrm{C}$ $\mathrm{m}^{-2} \mathrm{~d}^{-1}$, and total production was below $8 \mathrm{Tg} \mathrm{C}$ per season in the entire PFZ.

\subsubsection{Trends over the period 1997-2007}

Trends in seasonal mean NPP in five frontal zones over the past decade were examined, and the results are listed in 
Table 4. Kendall's rank correlations between NPP and SST in the five frontal zones.

\begin{tabular}{lrrrrr}
\hline Season & STZ & SAZ & PFZ & AAZ & SACCZ \\
\hline Spring & $\mathbf{- 0 . 6 6}$ & -0.11 & 0.11 & 0.02 & - \\
Summer & $\mathbf{- 0 . 5 4}$ & -0.11 & 0.29 & $-\mathbf{0 . 6 4}$ & $\mathbf{- 0 . 5 4}$ \\
Autumn & -0.36 & 0.38 & -0.04 & -0.36 & -0.47 \\
Winter & $\mathbf{0 . 5 6}$ & 0.29 & 0.47 & - & -
\end{tabular}

Bold numbers denote statistical significance at the $95 \%$ confidence level. In all cases, number of samples is 10 .

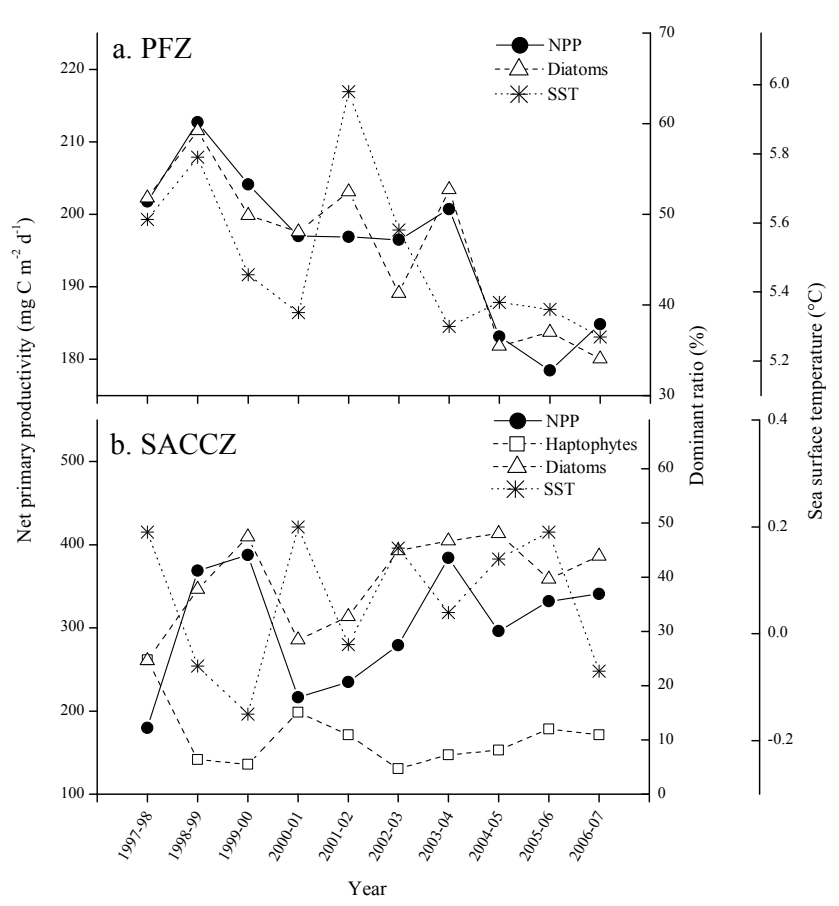

Fig. 3. Relationships between NPP, dominant phytoplankton groups and SST for (a) PFZ and (b) SACCZ from 1997 to 2007 during summer.

Table 3. A statistically significant reduction in summer NPP was found in the PFZ over the decade with the annual decline rate of ca. $3 \mathrm{mg} \mathrm{C} \mathrm{m}^{-2} \mathrm{~d}^{-1} \mathrm{y}^{-1}$. However, there were no significant trends in NPP in other frontal zones.

\subsection{Relationships between NPP, dominant phytoplank- ton groups, and SST}

\subsubsection{Relationships between NPP and SST}

Nonparametric Kendall's rank correlations $(\tau)$ between NPP and SST are shown in Table 4. During austral spring, seasonal averaged NPP negatively correlated with SST $(\tau=$ -0.66) in the Subtropical Frontal Zone (STZ). Similarly, during summer, NPP showed negative correlations with SST in the STZ, AAZ and SACCZ ( $\tau=-0.54,-0.64,-0.54$, respectively). There were no significant correlations between
Table 5. Kendall's rank correlations between the dominant ratios for each phytoplankton group determined by PHYSAT and (a) NPP or (b) SST in the five frontal zones.

\begin{tabular}{|c|c|c|c|c|c|}
\hline & STZ & SAZ & PFZ & AAZ & SACCZ \\
\hline \multicolumn{6}{|l|}{ (a) NPP } \\
\hline \multicolumn{6}{|c|}{ Spring } \\
\hline Haptophytes & -0.16 & 0.02 & -0.47 & -0.20 & - \\
\hline Prochlorococcus & -0.38 & -0.40 & - & - & - \\
\hline Synechococcus & 0.33 & 0.56 & - & - & - \\
\hline Diatoms & -0.14 & -0.56 & 0.33 & 0.24 & - \\
\hline \multicolumn{6}{|c|}{ Summer } \\
\hline Haptophytes & -0.24 & -0.48 & 0.00 & 0.11 & -0.54 \\
\hline Prochlorococcus & 0.11 & -0.33 & - & - & - \\
\hline Synechococcus & 0.42 & 0.20 & - & - & - \\
\hline Diatoms & -0.33 & 0.11 & 0.60 & 0.42 & 0.56 \\
\hline \multicolumn{6}{|c|}{ Autumn } \\
\hline Haptophytes & -0.02 & 0.00 & -0.60 & -0.07 & -0.04 \\
\hline Prochlorococcus & -0.07 & 0.09 & - & - & - \\
\hline Synechococcus & 0.16 & 0.18 & - & - & - \\
\hline Diatoms & -0.34 & -0.30 & 0.52 & 0.78 & 0.20 \\
\hline \multicolumn{6}{|c|}{ Winter } \\
\hline Haptophytes & -0.16 & 0.11 & -0.16 & - & - \\
\hline Prochlorococcus & -0.39 & -0.07 & - & - & - \\
\hline Synechococcus & 0.27 & 0.00 & - & - & - \\
\hline Diatoms & 0.00 & -0.47 & 0.03 & - & - \\
\hline (b) $\mathrm{SST}$ & & & & & \\
\hline \multicolumn{6}{|c|}{ Spring } \\
\hline Haptophytes & 0.30 & 0.39 & -0.34 & -0.24 & - \\
\hline Prochlorococcus & 0.61 & 0.00 & - & - & - \\
\hline Synechococcus & -0.57 & -0.29 & - & - & - \\
\hline Diatoms & 0.09 & 0.02 & 0.34 & 0.29 & - \\
\hline \multicolumn{6}{|c|}{ Summer } \\
\hline Haptophytes & 0.13 & -0.34 & -0.40 & 0.07 & 0.43 \\
\hline Prochlorococcus & -0.09 & -0.38 & - & - & - \\
\hline Synechococcus & -0.31 & -0.29 & - & - & - \\
\hline Diatoms & 0.13 & 0.42 & 0.42 & -0.24 & -0.36 \\
\hline \multicolumn{6}{|c|}{ Autumn } \\
\hline Haptophytes & 0.27 & 0.13 & 0.00 & -0.22 & 0.18 \\
\hline Prochlorococcus & -0.31 & -0.36 & - & - & - \\
\hline Synechococcus & -0.13 & -0.18 & - & - & - \\
\hline Diatoms & 0.41 & 0.34 & 0.14 & -0.22 & -0.33 \\
\hline \multicolumn{6}{|c|}{ Winter } \\
\hline Haptophytes & 0.11 & 0.20 & 0.20 & - & - \\
\hline Prochlorococcus & -0.20 & -0.16 & - & - & - \\
\hline Synechococcus & 0.00 & -0.45 & - & - & - \\
\hline Diatoms & 0.12 & -0.35 & -0.42 & - & - \\
\hline
\end{tabular}

Bold numbers denote statistical significance at the $95 \%$ confidence level. In all cases, number of samples is 10 .

NPP and SST in the five frontal zones during autumn. During winter, there was a positive correlation between NPP and SST in the $\operatorname{STZ}(\tau=0.56)$. 

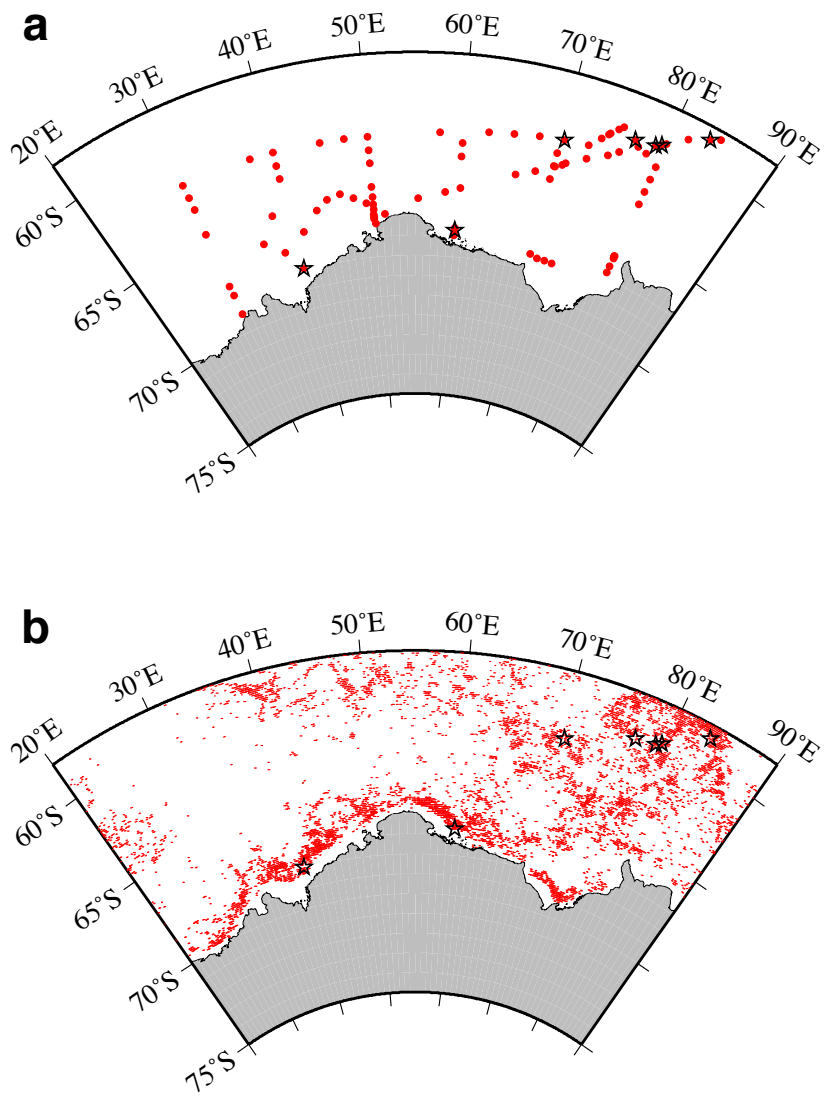

Fig. 4. Sites where diatoms were predominant during JanuaryFebruary 2006 as estimated by (a) CHEMTAX and (b) PHYSAT. Stars on the plots: Stations where both results were comparable to each other within \pm 1 pixel and \pm 2 days.

\subsubsection{Relationships between NPP and dominant phyto- plankton groups}

Relationships between the dominant ratios (DR) for each PFT derived from PHYSAT and seasonal averaged NPP are shown in Table 5a. During spring, NPP correlated with the DR for Synechococcus positively ( $\tau=0.56$ ), but the DR for diatoms negatively $(\tau=-0.56)$ in the Subantarctic Frontal Zone (SAZ). No significant correlations between the DR for PFTs and NPP were found in other frontal zones. During summer, the decreasing trend in NPP in the PFZ (Table 3 and Fig. 3a) positively correlated with the DR for diatoms $(\tau=0.60)$, while in the SACCZ, NPP correlated positively with the DR for diatoms $(\tau=0.56)$, but negatively with the DR for haptophytes ( $\tau=-0.54$ ) (Fig. 3b). Similar relationships between NPP and PFTs (diatoms and haptophytes) were found in the PFZ during autumn. During winter, in the five frontal zones there were no significant correlations between the DR for PFTs and NPP.

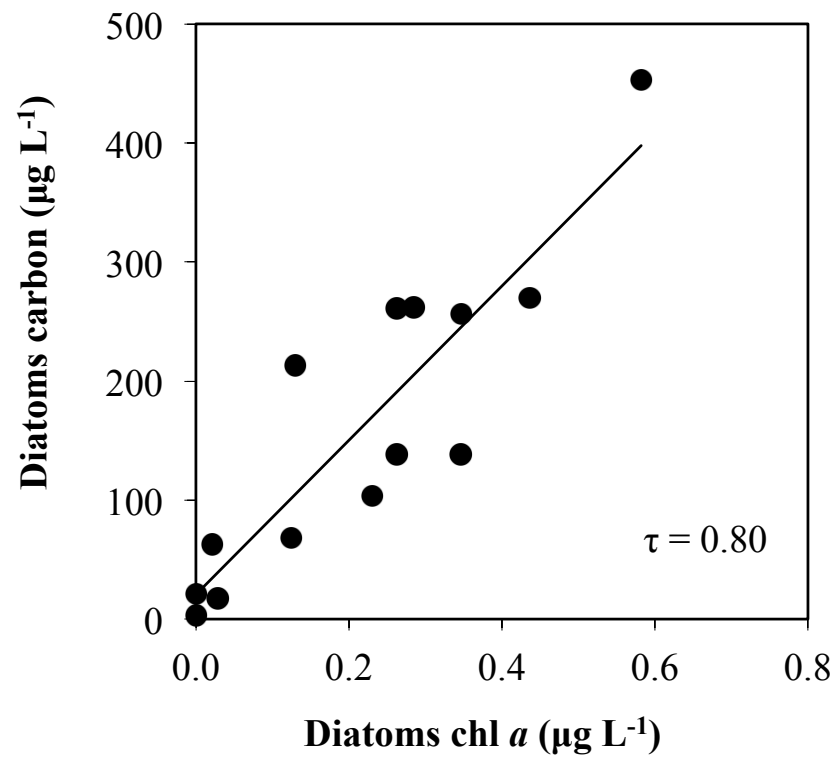

Fig. 5. Comparisons between chl $a$ levels and carbon derived from diatoms.

\subsubsection{Relationships between dominant phytoplankton groups and SST}

Relationships between the DR for each PFT derived from PHYSAT and seasonal averaged SST are shown in Table 5b. During spring, seasonal averaged SST in the STZ was positively correlated with the DR for Prochlorococcus ( $\tau=0.61$ ), but also negatively with the DR for Synechococcus $(\tau=-0.57)$. From summer to winter, in the five frontal zones there were no significant correlations between the DR for PFTs and SST.

\subsection{Comparisons between the results of PHYSAT and CHEMTAX}

During January-February 2006, the dominance of diatoms among the phytoplankton assemblages was observed as estimated by CHEMTAX and PHYSAT (Fig. 4). In terms of the predominance of diatoms, the PHYSAT outputs derived from daily ocean color data were matched with 10 out of 314 in situ pigment data. The estimates of PHYSAT were in good agreement with the results of CHEMTAX, that is, these matched at 7 out of 10 stations. The mismatches between PHYSAT and CHEMTAX were caused by green algae and cryptophytes as estimated from CHEMTAX (Table 6). However, in terms of the predominance of the three other dominating phytoplankton groups (i.e., haptophytes, Prochlorococcus, and Synechococcus), sufficient data were not available to validate the results of the PHYSAT performance. 
Table 6. Comparisons between CHEMTAX and PHYSAT results.

\begin{tabular}{lccccccc}
\hline Cruise & Latitude & Longitude & Date & Daydif & Pixeldif & CHEMTAX & PHYSAT \\
\hline UM2005/2006 & -44.66 & 22.52 & 6 Jan 2006 & -2 & 1 & green algae & diatoms \\
BROKE-West & -60.20 & 77.07 & 11 Jan 2006 & -1 & 1 & diatoms & diatoms \\
BROKE-West & -61.30 & 70.36 & 12 Jan 2006 & +2 & 1 & diatoms & diatoms \\
UM2005/2006 & -60.06 & 79.09 & 22 Jan 2006 & +1 & 1 & diatoms & diatoms \\
UM2005/2006 & -59.90 & 79.60 & 22 Jan 2006 & +1 & 1 & diatoms & diatoms \\
UM2005/2006 & -58.65 & 83.50 & 22 Jan 2006 & 0 & 1 & diatoms & diatoms \\
BROKE-West & -67.50 & 39.97 & 30 Jan 2006 & 0 & 0 & cryptophytes & diatoms \\
BROKE-West & -67.94 & 39.99 & 30 Jan 2006 & 0 & 1 & diatoms & diatoms \\
BROKE-West & -68.05 & 39.99 & 30 Jan 2006 & 0 & 1 & not dominant & diatoms \\
BROKE-West & -66.56 & 59.97 & 10 Feb 2006 & -1 & 1 & diatoms & diatoms \\
\hline
\end{tabular}

Daydif is given by the difference of date between in situ and satellite measurements; Pixeldif is given by the difference of pixel between in situ measurement and PHYSAT data.

\subsection{Comparison of CHEMTAX with microscopy}

In light microscopy, diatoms accounted for the highest proportion of the algal carbon biomass (44-99\%), and dinoflagellates made a smaller contribution $(0-52 \%)$ in our study area. Other algal groups identified were haptophytes, cryptophytes and nanoflagellates. In terms of carbon biomass, the diatom Corethron inerme dominated the diatom assemblages and contributed to ca. $30 \%$ of the diatom biomass. A significant correlation was found between diatom-derived chl $a$ estimated by CHEMTAX and diatom carbon biomass estimated by microscopy $(\tau=0.80, p<0.0001, n=14)$ (Fig. 5). At some stations, contributions of dinoflagellates to the carbon biomass were relatively high (i.e., maximum $52 \%$ ). However, dinoflagellate-derived chl $a$ levels had no relationship with their carbon biomass.

\section{Discussion}

\subsection{Validations of satellite-derived phytoplankton com- position in the Southern Ocean}

Validation of PHYSAT in the Southern Ocean has never been carried out except for coastal waters along the WAP (Alvain et al., 2008, 2012). The authors reported that a significant fraction $(73 \%)$ of diatoms estimated by PHYSAT were in good agreement with the results based on the pigment inventory of diatoms in global daily products (Alvain et al., 2012). Here we tried, for the first time, to validate PHYSAT performance in the Southern Ocean other than seas around the WAP, using in situ phytoplankton pigment and algal species data measured with HPLC and light microscopy, respectively (Sects. 3.3 and 3.4). In this study, we did not follow the validation process of Alvain et al. $(2008,2012)$, because in our HPLC pigment data, only $19 \%$ of the whole data (60 out of 314 samples) matched the criteria for pigment data by Alvain et al. (2005) (see Table 4 of Alvain et al., 2005, for details). Therefore, CHEMTAX was used to validate the PHYSAT performance. For diatoms, the estimates of PHYSAT derived from daily ocean color data were in good agreement with the results of CHEMTAX in the Indian sector of the Southern Ocean (i.e., 7 out of 10 stations; Table 6). In order to check for disparities between the estimates of PHYSAT and those of CHEMTAX, both procedures were conducted using the 60 HPLC pigment data (see above). The predominance of diatoms among the phytoplankton assemblages was also observed by analyzing the 60 pigment data with CHEMTAX. In terms of the dominance of diatoms, the PHYSAT outputs, which estimated from HPLC pigment data and the criteria of Alvain et al. (2005), matched at 32 out of 39 data in CHEMTAX (i.e., $82 \%$ ). Thus, the results represent that the validation of PHYSAT with respect to the DR for diatoms estimated from ocean color data succeeded in the Indian sector of the Southern Ocean.

Recently, Kozlowski et al. (2011) reported that a subtle but insignificant difference was found among CHEMTAX methods where randomized error, feedback loops and additional diagnostic pigments were taken into account (Latasa, 2007; Wright et al., 2009). In this study, a part of BROKEWest cruise data (Sect. 2.2) is incorporated, and the chemotaxonomic pigment analysis has been reported in Wright et al. (2010). Although CHEMTAX procedures between Wright et al. (2010) and our study were different from each other, both CHEMTAX estimates in diatoms showed a good agreement $\left(r^{2}=0.89, p<0.00001, n=115\right.$; data not shown). A significant correlation was also found between diatom-derived chl $a$ estimated by CHEMTAX and carbon biomass of diatoms estimated by microscopy (Fig. 5), indicating that our CHEMTAX estimates were sufficiently reliable. Good correlations between the results of the two techniques have also been confirmed by several studies (e.g., Garibotti et al., 2003; Llewellyn et al., 2005; Suzuki et al., 2011), and those could be mainly due to both the ease of sample fixation and rather simple identification for diatoms in microscopy. 
At some stations, contributions of dinoflagellates to the algal carbon biomass were relatively high. However, dinoflagellate-derived $\operatorname{chl} a$ levels had no relationship with their carbon biomass (Sect. 3.4). In the Australian sector of SAZ, de Salas et al. (2011) reported that dinoflagellates lacking peridinin, that is, heterotrophic cells or those containing fucoxanthin and its derivatives instead, were important contributors to the carbon biomass of total dinoflagellates. In our microscope observations, autotrophic dinoflagellates were not distinguished from heterotrophic ones, because we examined neither the presence of chloroplasts nor in vivo chlorophyll fluorescence in the samples. Furthermore, dinoflagellates containing fucoxanthin derivatives are difficult to distinguish from haptophytes by pigment analysis. Thus, the discrepancy between dinoflagellate chl $a$ levels derived from peridinin and their carbon biomass in this study is likely due to the presence of heterotrophic dinoflagellates or autotrophic cells lacking peridinin.

\subsection{Trends over the period 1997-2007}

Inter-annual variations in seasonal averaged NPP were obtained in five frontal zones over the past decade (1997-2007; Table 2). In the PFZ, a statistically significant reduction in NPP was found over the decade during austral summer. The decline rate of NPP in the PFZ was ca. $3 \mathrm{mg} \mathrm{C} \mathrm{m}^{-2} \mathrm{~d}^{-1} \mathrm{y}^{-1}$ (Table 3). Furthermore, the decreasing trend in NPP positively correlated with the DR for diatoms, but did not correlate with SST (Fig. 3a). Since the PFZ represents a highnutrient, low-chlorophyll (HNLC) region, it was likely that iron availability limited the growth of the phytoplankton, in particular diatoms (Martin et al., 1990; de Baar et al., 1995). Several studies reported that diatom-dominated blooms were associated with the PF (Laubscher et al., 1993; Landry et al., 2002), and it was argued that this was due to increased iron availability in frontal regions (de Baar et al., 1995; Bathmann et al., 1997). Although we analyzed satellite data with climatological locations of the four fronts and five frontal zones, Sokolov and Rintoul (2009) showed that, in the circumpolar average, each of the ACC fronts shifted to the south over the period 1992-2007. This could lead to a change in iron availability in frontal regions by means of meander-induced upwelling and/or enhanced eddy mixing. Alternatively, Landry et al. (2002) suggested that strong zooplankton grazing pressure might control phytoplankton biomass in the PFZ. Thus, a potential explanation for the significant reduction in NPP in the PFZ during austral summer might be the complex interactions between bottom-up (e.g., iron availability) and topdown (e.g., grazing) controls of the diatoms.

In the SACCZ where seasonal sea ice cover exists, interannual variations in NPP were highest among the five frontal zones during austral summer, and the difference between the highest and lowest values exceeded $100 \mathrm{Tg} \mathrm{C}$ per season. Although there was no significant trend in NPP over the decade, NPP correlated with not only the DR for diatoms positively, but also the DR for haptophytes and SST negatively (Fig. 3b). In the sea ice zone of the south Indian Ocean and a large fraction of the southwest Pacific Ocean sector $\left(>50^{\circ} \mathrm{S}, 20\right.$ $\left.160^{\circ} \mathrm{E}\right)$, Arrigo et al. (2008) also reported a strong negative correlation between anomalies of SST and mean annual primary production derived from satellite remote sensing data. However, it was difficult to show a plausible explanation for the negative correlation between SST and annual primary production (Arrigo et al., 2008). South of $60^{\circ} \mathrm{S}$, Smith and Comiso (2008) showed that the spatial distribution of SST was strongly influenced by sea ice melting. Previous studies also suggested that sea ice melting caused the changes in the mixed layer depth (Mitchell and Holm-Hansen, 1991; Vernet et al., 2008) and iron availability (Lannuzel et al., 2007, 2008; van der Merwe et al., 2011), affecting the magnitude of NPP and phytoplankton community composition (e.g., Arrigo et al., 1999; Boyd et al., 2000; Coale et al., 2004; Westwood et al., 2010). Thus, the large variation in NPP in the SACCZ was possibly related to the extent of sea ice cover, which was highly changeable from year to year (Zhang, 2007; Cavalieri and Parkinson, 2008). Further studies must be needed to clarify the relationship between sea ice and NPP in the SACCZ.

\subsection{Relationships between NPP, dominant phytoplank- ton groups, and SST}

Most previous studies assessing the relationships between NPP, phytoplankton community composition, and SST in the Southern Ocean considered rather limited regions such as the Ross Sea, coastal waters along the WAP and vicinities of islands, or only point observations (e.g., Claustre et al., 1997; Arrigo et al., 2000; Korb et al., 2005; Seeyave et al., 2007; Uitz et al., 2009). However, here we assessed, for the first time, the relationships between NPP, dominant phytoplankton groups, and SST in the Indian sector of the Southern Ocean over the past decade (1997-2007) using monthly satellite remote sensing data. Since daily ocean color data are rather scarce in high latitudes even during summer, the use of monthly data is common in studies of the Southern Ocean (e.g., Smith et al., 2001, 2008; Moore and Doney, 2006; Johnston and Gabric, 2011). In the STZ during winter, where NPP positively correlated with SST (Table 4), photosynthetic rates typically increased with increasing water temperatures within the temperature range to which the cells can adapt (Eppley, 1972; Neori and Holm-Hansen, 1982). However, NPP negatively correlated with SST in the STZ during austral spring to summer and in the AAZ and SACCZ during summer (Table 4). Since subtropical waters in the STZ are generally nutrient-depleted (Longhurst, 2006), it was likely that nutrient supply limited the growth of the phytoplankton (Read et al., 2000). Recently, Fauchereau et al. (2011) found a positive correlation between chl $a$ and mixed layer depth in the Southern Ocean north of $40^{\circ} \mathrm{S}$ during October and March (i.e., austral spring-summer) using a combination of 
satellite remote sensing and model data. Therefore, the negative correlation between NPP and SST in the STZ during austral spring to summer was possibly related to the variability of mixed layer depth, which can affect the variability of SST. However, very few studies reported negative correlation between NPP and SST in areas south of $50^{\circ} \mathrm{S}$ (e.g., Arrigo et al., 2008). Enhanced NPP with decreasing SST in seasonal ice zone, as we mentioned in Sect. 4.2, could be caused by sea ice melting and followed by changes in the mixed layer depth and iron availability. Unlike the PFZ, where strong zooplankton grazing pressure might control phytoplankton biomass (Landry et al., 2002), previous studies in the seasonal ice zone of the Southern Ocean suggested that the microzooplankton grazing impact was considerably reduced by low temperature (Burkill et al., 1995; Tsuda and Kawaguchi, 1997). In the marginal ice zone of the Bellingshausen Sea, Burkill et al. (1995) showed that the magnitude of microzooplankton grazing was correlated positively with ambient seawater temperature, but this was compromised by much lower prey concentrations observed at the colder sites. Thus, the enhanced NPP with decreasing SST could be partly due to low zooplankton herbivory with low water temperature.

No significant correlations between the DR for each phytoplankton group determined by PHYSAT and SST values based on three-monthly results (i.e., seasonal mean) were found in the Indian sector of the Southern Ocean throughout the year except in the STZ during spring (Table 5b). This suggests that other environmental factors are more important than the direct effect of temperature on phytoplankton community composition in our study area. During spring (September-October) in the STZ, Zubkov et al. (1998) reported that the abundance of Prochlorococcus estimated by flow cytometry reached maxima in equatorial waters, and their cells completely disappeared south of $38^{\circ} \mathrm{S}$, while Synechococcus spp. occurred with high concentrations in the upwelling region and in the frontal region and they were still present south of $38^{\circ} \mathrm{S}$. As a result, SST correlated with not only the abundance of Prochlorococcus positively, but also Synechococcus spp. negatively in the STZ (Zubkov et al., 1998). Their results were consistent with ours based on satellite remote sensing data in the STZ during austral spring (Table $5 b$ ).

During austral summer to autumn, NPP positively correlated with the DR for diatoms in several frontal zones (Table 5a). The results are also consistent with previous studies. For example, around the Crozet Islands in the PFZ, phytoplankton productivity and community structure were closely linked: the high production was supported with diatoms during the early bloom period (Seeyave et al., 2007). Korb et al. (2005) also reported high primary production and microphytoplankton (mainly diatoms) dominated production in the AAZ northwest of South Georgia. Moreover, several studies reported the taxonomic dependency of phytoplankton specific absorption coefficients in the Antarctic coastal waters (e.g., Claustre et al., 1997). Bracher et al. (1999) also found that values of maximum quantum yield of carbon fixation were high in surface waters of the PF, where contributions of diatoms to the total phytoplankton biomass accounted for $60-80 \%$. Thus, changes in the phytoplankton community composition can strongly affect the variability of NPP in the Southern Ocean.

\subsection{Impact of the Southern Annular Mode}

Although this study mainly focused on recent climate change such as SST, previous studies examined linkages between regional-specific climatic variations such as the Southern Annular Mode (SAM) index and chl sat or NPP derived from ocean color data (Lovenduski and Gruber, 2005; Arrigo et al., 2008; Johnston and Gabric, 2011). Lovenduski and Gruber (2005) reported that $\mathrm{chl}_{\mathrm{sat}}$ anomalies from 1997 to 2004 in areas south of the PF were correlated not only with SAM index positively, but also with SST negatively. Their study also found positive phases of the SAM were also associated with enhanced westerly winds over the AAZ and PFZ, driving increased equatorward Ekman transport and cold SST anomalies in these regions. As a consequence, the positive correlation between chl sat and the SAM index could be due to the supply of cold, iron-rich waters by upwelling (Lovenduski and Gruber, 2005). However, the correlations between chl $\mathrm{sat}_{\mathrm{s}}$ and the SAM index in Lovenduski and Gruber (2005) were significant only in the SAZ south of Western Australia. Arrigo et al. (2008) concluded that SAM explained $31 \%$ of the variations in satellite-based annual primary production in the Southern Ocean, but the result was statistically insignificant $(p=0.12)$. Recently, in the Australian sector of the Southern Ocean $\left(40-70^{\circ} \mathrm{S}, 110-160^{\circ} \mathrm{E}\right)$, Johnston and Gabric (2011) found a significant positive correlation between both summer chl $\mathrm{sat}_{\text {at }}$ or NPP and the SAM index in the $65-70^{\circ} \mathrm{S}$ (i.e., SACCZ in this study) over the past decade (1997-2007). In this study, summer NPP in areas south of the PF (i.e., the AAZ and SACCZ) were significantly correlated with SST (Table 4). In addition to the effects of sea ice melting as we mentioned in the Sect. 4.2, the regional-specific climatic variations such as SAM could possibly be related to the enhanced NPP with decreasing SST in seasonal ice zone.

Although very few studies investigated relationships between phytoplankton community compositions and SAM, Montes-Hugo et al. (2008) found no clear relationship between inter-annual variability of SAM and satellite-derived phytoplankton size structure index in coastal waters along the WAP during spring-summer of 1997-2006. Recently, CHEMTAX analysis of phytoplankton pigment signatures along the transect of the icebreaker l'Astrolabe between Tasmania and Dumont d'Urville, Antarctica (WOCE SR3 transect) found that changes in HPLC chlorophyll concentrations associated with SAM were mostly due to diatoms and haptophytes type 8 and/or dinoflagellates type 2 (S. W. Wright, personal communication, 2012); however, this transect may be atypical due to complex frontal structures. 
Thus, relationships between phytoplankton community compositions and the specific regional climatic variations (e.g., SAM) need to be carefully considered based on both field and satellite data in several regions in the Southern Ocean.

\section{Conclusions}

This study represented the first attempt to clarify the relationships between NPP, dominant phytoplankton groups, and SST in the Indian sector of the Southern Ocean over the past decade (1997-2007) using satellite remote sensing data. When trends in the summer time series for NPP were examined, we found over the decade within the PFZ a statistically significant reduction of NPP. Furthermore, the decreasing trend in NPP positively correlated with the DR for diatoms estimated by PHYSAT. In the seasonal ice zone (i.e., SACCZ) during summer, NPP correlated not only with the DR for diatoms positively, but also with the DR for haptophytes and SST negatively. These results strongly suggested that summer NPP values were affected by the phytoplankton community composition in the Indian sector of the Southern Ocean. However, conventional algorithms for the estimates of phytoplankton community composition still need to be improved. For example, although the greater dominance of cryptophytes over diatoms in coastal waters along the WAP has been hypothesized as a response to the regional warming (e.g., Moline et al., 2004), no phytoplankton community composition algorithms allow us to estimate the spatiotemporal distributions of cryptophytes. Moreover, several studies reported taxonomic differences in photosynthetic physiology among phytoplankton groups (e.g., Claustre et al., 1997; Bracher et al., 1999). Although Uitz et al. (2009) assessed phytoplankton size class-specific primary production in the Kerguelen Islands region of the Southern Ocean, the class-specific physiological parameters were derived from temperate and tropical oceanic regions. An extensive field dataset including the phytoplankton class-specific photosynthetic properties in the Southern Ocean is needed to elucidate the relationships between the class-specific primary production and environmental parameters using satellite remote sensing.

\section{Appendix A}

\section{Validation of the absorption-based primary productivity model}

Figure A1 shows the result of validation of satellite-derived NPP data with the method of Hirawake et al. (2011) and additional 10 in situ NPP data from Uitz et al. (2009). The NPP derived from daily ocean color data matched with 4 out of 10 in situ data within \pm 1 pixel and \pm 1 day. If we use 13 in situ NPP data, that is, 9 from Hirawake et al. (2011) and 4 from Uitz et al. (2009), the satellite NPP values are in good

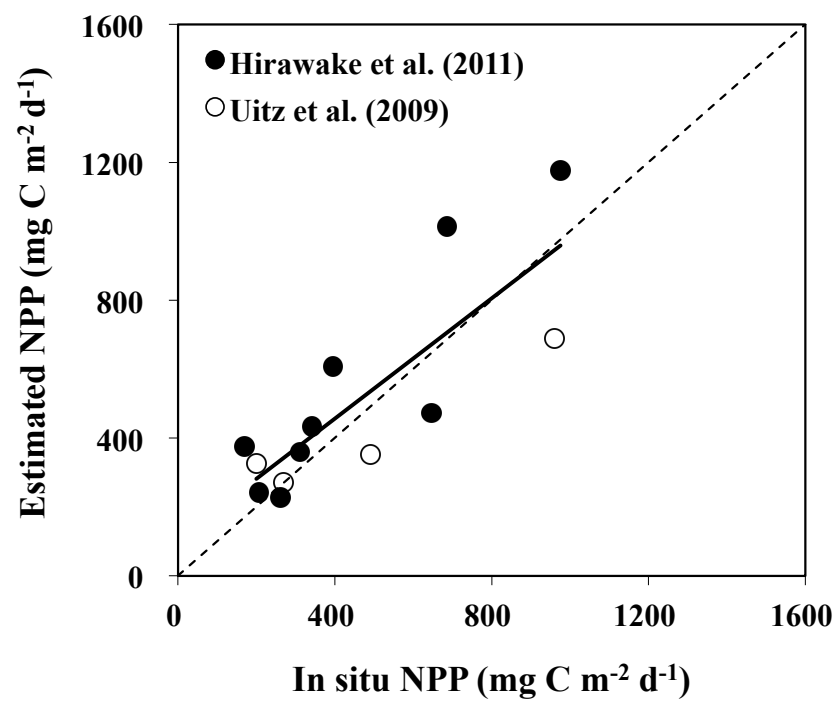

Fig. A1. A comparison between in situ NPP and satellite NPP estimated by the method of Hirawake et al. (2011). Solid and dashed lines indicate the regression line and 1:1 line, respectively.

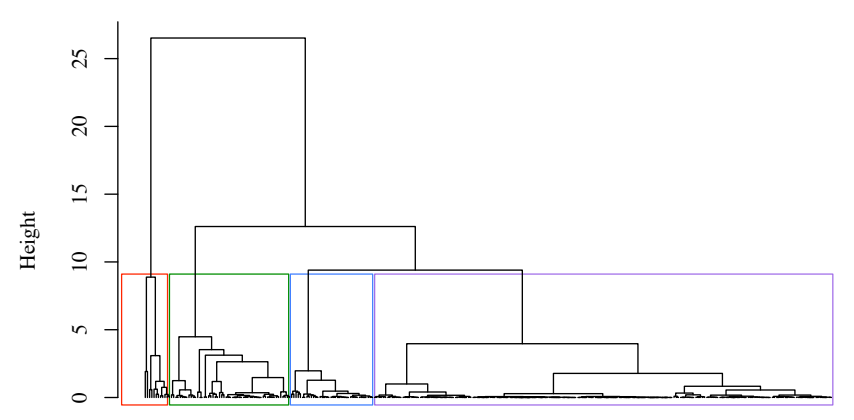

Fig. A2. Cluster analysis of pigment data. Framed rectangles in red, green, blue, and purple represent cluster group A, B, C and D, respectively.

agreement with the in situ NPP $\left(r^{2}=0.68\right.$, slope $=0.87$, RMS $=0.16, p<0.001)$ in the Indian sector of the Southern Ocean. RMS means root mean square of the log-difference error.

\section{Appendix B}

\section{Cluster analysis of pigment data}

For the CHEMTAX calculations, a hierarchical cluster analysis by the Ward method (Ward, 1963) was used to classify the 314 pigment data into groups. These data were successfully categorized into the four groups (Fig. A2): Cluster A (i.e., Group A in Table 1) is characterized as very high chl $a$ and fucoxanthin concentrations. On the other hand, cluster D has relatively low pigment concentrations. Cluster B and C show relatively high $19^{\prime}$-butanoyloxyfucoxanthin and chlorophyll $b$ concentrations, and alloxanthin level, 


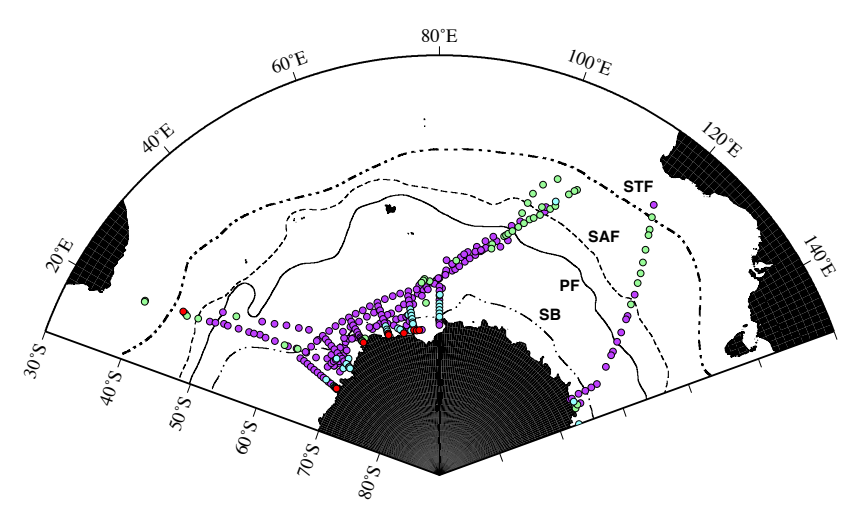

Fig. A3. Distributions of the four cluster groups. Circles in red, green, blue, and purple represent cluster group A, B, C and D, respectively.

respectively. Figure A3 shows the distributions of the four cluster groups in our study area.

Acknowledgements. We would like to thank the captain and crews of the TR/V Umitaka-Maru, and many other colleagues on board for their assistance in collecting samples during the cruises. We thank the Distributed Active Archive Center (DAAC) at the Goddard Space Flight Center and DAAC at the Physical Oceanography for the production and distribution of satellite data. Thanks are also given to Séverine Alvain for providing the PHYSAT look-up-table and constructive comments. Finally, we appreciate the editor and an anonymous reviewer for providing valuable comments that improved the manuscript significantly. This work was partly supported by the Japan Society for the Promotion of Science (JSPS), JARE STAGE program, JAXA GCOM-C program and the Australian government's Cooperative Research Centres Programme through the Antarctic Climate and Ecosystems Cooperative Research Centre (ACE CRC).

Edited by: A. Bricaud

\section{References}

Alvain, S., Moulin, C., Dandonneau, Y., and Breon, F. M.: Remote sensing of phytoplankton groups in case 1 waters from global SeaWiFS imagery, Deep-Sea Res. Pt. I, 52, 1989-2004, 2005.

Alvain, S., Moulin, C., Dandonneau, Y., and Loisel, H.: Seasonal distribution and succession of dominant phytoplankton groups in the global ocean: A satellite view, Global Biogeochem. Cy., 22, GB3001, doi:10.1029/2007GB003154, 2008.

Alvain, S., Loisel, H., and Dessailly, D.: Theoretical analysis of ocean color radiances anomalies and implications for phytoplankton groups detection in case 1 waters, Opt. Express, 20, 1070-1083, 2012.

Arrigo, K. R., Robinson, D. H., Worthen, D. L., Dunbar, R. B., DiTullio, G. R., van Woert, M., and Lizotte, M. P.: Phytoplankton community structure and the drawdown of nutrients and $\mathrm{CO}_{2}$ in the Southern Ocean, Science, 283, 365-367, 1999.
Arrigo, K. R., DiTullio, G. R., Dunbar, R. B., Robinson, D. H., VanWoert, M., Worthen, D. L., and Lizotte, M. P.: Phytoplankton taxonomic variability in nutrient utilization and primary production in the Ross Sea, J. Geophys. Res., 105, C4, doi:10.1029/1998JC000289, 2000.

Arrigo, K. R., van Dijken, G. L., and Bushinsky, S.: Primary production in the Southern Ocean, 1997-2006, J. Geophys. Res., 133, C08004, doi:10.1029/2007JC004551, 2008.

Bailey, S. W. and Werdell, P. J.: A multi-sensor approach for the onorbit validation of ocean color satellite data products, Remote. Sens. Environ., 102, 12-23, 2006.

Bathmann, U. V., Scharek, R., Klaas, C., Dubischar, C. D., and Smetacek, V.: Spring development of phytoplankton biomass and composition in major water masses of the Atlantic sector of the Southern Ocean, Deep-Sea Res. Pt. II, 44, 51-67, 1997.

Behrenfeld, M. J. and Falkowski, P. G.: Photosynthetic rates derived from satellite-based chlorophyll concentration, Limnol. Oceanogr., 42, 1-20, 1997.

Behrenfeld, M. J., O’Malley, R. T., Siegel, D. A., McClain, C. R., Sarmiento, J. L., Feldman, G. C., Milligan, A. J., Falkowski, P. G., Letelier, R. M., and Boss, E. S.: Climate-driven trends in contemporary ocean productivity, Nature, 444, 752-755, 2006.

Belkin, I. M. and Gordon, A. L.: Southern Ocean fronts from the Greenwich meridian to Tasmania, J. Geophys. Res., 101, 36753696, doi:10.1029/95JC02750, 1996.

Boyd, P. W., Watson, A. J., Law, C. S., Abraham, E. R., Trull, T., Murdoch, R., Bakker, D. C. E., Bowie, A. R., Buesseler, K. O., Chang, H., Charette, M., Croot, P., Downing, K., Frew, R., Gall, M., Hadfield, M., Hall, J., Harvey, M., Jameson, G., LaRoche, J., Liddicoat, M., Ling, R., Maldonado, M. T., McKay, R. M., Nodder, S., Pickmere, S., Pridmore, R., Rintoul, S., Safi, K., Sutton, P., Strzepek, R., Tanneberger, K., Turner, S., Waite, A., and Zeldis, J.: A mesoscale phytoplankton bloom in the polar Southern Ocean stimulated by iron fertilization, Nature, 407, 695-702, 2000.

Bracher, A. U., Kroon, B. M. A., and Lucas, M. I.: Primary production, physiological state and composition of phytoplankton in the Atlantic Sector of the Southern Ocean, Mar. Ecol.-Prog. Ser., 190, 1-16, 1999.

Brock, T. D.: Calculating solar radiation for ecological studies, Ecol. Model., 14, 1-19, 1981.

Buitenhuis, E., van der Wal, P., and de Baar, H.: Blooms of Emiliania huxleyi are sinks of atmospheric carbon dioxide: A field and mesocosm study derived simulation, Global Biogeochem. Cy., 15, 577-587, doi:10.1029/2000GB001292, 2001.

Burkill, P. H., Edwards, E. S., and Sleigh, M. A.: Microzooplankton and their role in controlling phytoplankton growth in the marginal ice zone of the Bellingshausen Sea, Deep-Sea Res. Pt. II, 42, 1277-1290, 1995.

Cavalieri, D. J. and Parkinson, C. L.: Antarctic sea ice variability and trends, 1979-2006, J. Geophys. Res., 113, C07004, doi:10.1029/2007JC004564, 2008.

Claustre, H., Moline, M. A., and Prézelin, B. B.: Sources of variability in the column photosynthetic cross section for Antarctic coastal waters, J. Geophys. Res., 102, C11, doi:10.1029/96JC02439, 1997.

Coale, K. H., Johnson, K. S., Chavez, F. P., Buesseler, K. O., Barber, R. T., Brzezinski, M. A., Cochlan, W. P., Millero, F. J., Falkowski, P. G., Bauer, J. E., Wanninkhof, R. H., Kudela, R. 
M., Altabet, M. A., Hales, B. E., Takahashi, T., Landry, M. R., Bidigare, R. R., Wang, X., Chase, Z., Strutton, P. G., Friederich, G. E., Gorbunov, M. Y., Lance, V. P., Hilting, A. K., Hiscock, M. R., Demarest, M., Hiscock, W. T., Sullivan, K. F., Tanner, S. J., Gordon, R. M., Hunter, C. N., Elrod, V. A., Fitzwater, S. E., Jones, J. L., Tozzi, S., Koblizek, M., Roberts, A. E., Herndon, J., Brewster, J., Ladizinsky, N., Smith, G., Cooper, D., Timothy, D., Brown, S. L., Selph, K. E., Sheridan, C. C., Twining, B. S., and Johnson, Z. I.: Southern Ocean iron enrichment experiment: carbon cycling in high- and low-Si waters, Science, 304, 408-414, 2004.

Comiso, J. C., McClain, C. R., Sullivan, C. W., Ryan, J. P., and Leonard, C. L.: Coastal Zone Color Scanner pigment concentrations in the Southern Ocean and relationships to geophysical surface features, J. Geophys. Res., 98, 2419-2451, doi:10.1029/92JC02505, 1993.

de Baar, H. J. W., de Jong, J. T. M., Bakker, D. C. E., Löscher, B. M., Veth, C., Bathmann, U., and Smetacek, V.: Importance of iron for plankton blooms and carbon dioxide drawdown in the Southern Ocean, Nature, 373, 412-415, 1995.

de Salas, M. F., Eriksen, R., Davidson, A. T., and Wright, S. W.: Protistan communities in the Australian sector of the Sub-Antarctic Zone during SAZ-SENSE, Deep-Sea Res. Pt. II, 58, 2135-2149, 2011.

DiTullio, G. R., Grebmeier, J. M., Arrigo, K. R., Lizotte, M. P., Robinson, D. H., Leventer, A., Barry, J. P., VanWoert, M. L., and Dunbar, R. B.: Rapid and early export of Phaeocystis antarctica blooms in the Ross Sea, Antarctica, Nature, 404, 595-598, 2000.

Doney, S. D.: Plankton in a warmer world, Nature, 444, 695-696, 2006.

Eppley, R. W.: Temperature and phytoplankton growth in the sea, Fish. B.-Noaa, 70, 1063-1085, 1972.

Fauchereau, N., Tagliabue, A., Bopp, L., and Monteiro, P. M. S.: The response of phytoplankton biomass to transient mixing events in the Southern Ocean, Geophys. Res. Lett., 38, L17601, doi:10.1029/2011GL048498, 2011.

Fouilland, E., Descolas-Gros, C., Courties, C., and Pons, V.: Autotrophic carbon assimilation and biomass from size-fractionated phytoplankton in the surface waters across the subtropical frontal zone (Indian Ocean), Polar Biol., 21, 90-96, 1999.

Frankignoulle, M., Canon, C., and Gattuso, J.-P.: Marine calcification as a source of carbon dioxide: Positive feedback of increasing atmospheric $\mathrm{CO}_{2}$, Limnol. Oceanogr., 39, 458-462, 1994.

Garibotti, I. A., Vernet, M., Kozlowski, W. A., and Ferrario, M. E.: Composition and biomass of phytoplankton assemblages in coastal Antarctic waters: a comparison of chemotaxonomic and microscopic analyses, Mar. Ecol.-Prog. Ser., 247, 27-42, 2003.

Gordon, A. L.: Interocean exchange, in: Ocean circulation and climate; observing and modelling the global ocean, edited by: Siedler, G., Church, J., and Gould, J., Academic Press, 2001.

Hashihama, F., Hirawake, T., Kudoh, S., Kanda, J., Furuya, K., Yamaguchi, Y., and Ishimaru, T.: Size fraction and class composition of phytoplankton in the Antarctic marginal ice zone along the $140^{\circ}$ E meridian during February-March 2003, Polar Science, 2, 109-120, 2008.

Hirata, T., Hardman-Mountford, N. J., Brewin, R. J. W., Aiken, J., Barlow, R., Suzuki, K., Isada, T., Howell, E., Hashioka, T., Noguchi-Aita, M., and Yamanaka, Y.: Synoptic relationships between surface Chlorophyll- $a$ and diagnostic pigments specific to phytoplankton functional types, Biogeosciences, 8, 311-327, doi:10.5194/bg-8-311-2011, 2011.

Hirawake, T., Takao, S., Horimoto, N., Ishimaru, T., Yamaguchi, Y., and Fukuchi, M.: A phytoplankton absorption-based primary productivity model for remote sensing in the Southern Ocean, Polar Biol., 34, 291-302, 2011.

Hillebrand, H., Dürselen, C-D., Kirschtel, D., Pollingher, U., and Zohry, T.: Biovolume calculation for pelagic and benthic microalgae, J. Phycol., 35, 403-424, 1999.

Johnston, B. M. and Gabric, A. J.: Interannual variability in estimated biological productivity in the Australian sector of the Southern Ocean in 1997-2007, Tellus, 63B, 266-286, 2011.

Korb, R. E., Whitehouse, M. J., Thorpe, S. E., and Gordon, M.: Primary production across the Scotia Sea in relation to the physicochemical environment, J. Marine Syst., 57, 231-249, 2005.

Kozlowski, W. A., Deutschman, D., Garibotti, I., Trees, C., and Vernet, M.: An evaluation of the application of CHEMTAX to Antarctic coastal pigment data, Deep-Sea Res. Pt. I, 58, 350364, 2011.

Landry, M. R., Selph, K. E., Brown, S. L., Abbott, M. R., Measures, C. I., Vink, S., Allen, C. B., Calbet, A., Christensen, S., and Nolla, H.: Seasonal dynamics of phytoplankton in the Antarctic Polar Front region at $170^{\circ} \mathrm{W}$, Deep-Sea Res. Pt. II, 49, $1843-$ 1865, 2002.

Lannuzel, D., Schoemann, V., de Jong, J., Tison, J.-L., and Chou, L.: Distribution and biogeochemical behaviour of iron in the East Antarctic sea ice, Mar. Chem., 106, 18-32, 2007.

Lannuzel, D., Schoemann, V., de Jong, J., Chou, L., Delille, B., Becquevort, S., and Tison, J.-L.: Iron study during a time series in the western Weddell pack ice, Mar. Chem., 108, 85-95, 2008.

Latasa, M.: Improving estimations of phytoplankton class abundances using CHEMTAX, Mar. Ecol. -Prog. Ser., 329, 13-21, 2007.

Laubscher, R. K., Perissinotto, R., and McQuaid, C. D.: Phytoplankton production and biomass at frontal zones in the Atlantic sector of the Southern Ocean, Polar Biol., 13, 471-481, 1993.

Lee, Z., Carder, K. L., and Arnone, R. A.: Deriving inherent optical properties from water color: a multiband quasi-analytical algorithm for optically deep waters, Appl. Optics, 41, 5755-5772, 2002.

Lee, Z., Weidemann, A., Kindle, J., Arnone, R. A., Carder, K. L., and Davis, C.: Euphotic zone depth: Its derivation and implication to ocean-color remote sensing, J. Geophys. Res., 112, C03009, doi:10.1029/2006JC003802, 2007.

Llewellyn, C. A., Fishwick, J. R., and Blackford, J. C.: Phytoplankton community assemblage in the English Channel: a comparison using chlorophyll $a$ derived from HPLC-CHEMTAX and carbon derived from microscopy cell counts, J. Plankton Res., 27, 103119, 2005.

Longhurst, R.: Ecological Geography of the Sea, 2nd Edn., Academic Press, 560 pp., 2006.

Lovenduski, N. S. and Gruber, N.: Impact of the Southern Annular Mode on Southern Ocean circulation and biology, Geophys. Res. Lett., 32, L11603, doi:10.1029/2005GL022727, 2005.

Mackey, M. D., Mackey, D. J., Higgins, H. W., and Wright, S. W.: CHEMTAX-a program for estimating class abundances from chemical makers: application to HPLC measurements of phytoplankton, Mar. Ecol.-Prog. Ser., 144, 265-283, 1996. 
Marchant, H. J., Davidson, A. T., and Wright, S. W.: The distribution and abundance of chroococcoid cyanobacteria in the Southern Ocean, Proc. NIPR Symp. Polar Biol., 1, 1-9, 1987.

Martin, J. H., Gordon, R. M., and Fitzwaters, S. E.: Iron in Antarctic waters, Nature, 345, 156-158, 1990.

McNeil, B. I., Metzl, N., Key, R. M., Matear, R. J., and Corbiere, A.: An empirical estimate of the Southern Ocean air-sea $\mathrm{CO}_{2}$ flux, Global Biogeochem. Cy., 21, GB3011, doi:10.1029/2007GB002991, 2007.

Mitchell, B. G. and Holm-Hansen, O.: Observations and modeling of the Antarctic phytoplankton crop in relation to mixing depth, Limnol. Oceanogr., 38, 981-1007, 1991.

Moline, M. A., Claustre, H., Frazer, T. K., Schofield, O., and Vernet, M.: Alteration of the food web along the Antarctic Peninsula in response to a regional warming trend, Global Change Biol., 10, 1973-1980, 2004.

Montagnes, D. J. S., Berges, J. A., Harrison, P. J., and Taylor, F. J. R.: Estimating carbon, nitrogen, protein, and chlorophyll a from volume in marine phytoplankton, Limnol. Oceanogr., 39, 10441060, 1994

Montes-Hugo, M. A., Vernet, M., Martinson, D., Smith, R., and Iannuzzi, R.: Variability on phytoplankton size structure in the western Antarctic Peninsula (1997-2006), Deep-Sea Res. Pt. II, 55, 2106-2117, 2008.

Montes-Hugo, M., Doney, S. C., Ducklow, H. W., Fraser, W., Martinson, D., Stammerjohn, S. E., and Schofield, O.: Recent changes in phytoplankton communities associated with rapid regional climate change along the Western Antarctic Peninsula, Science, 323, 1470-1473, 2009.

Moore, J. K. and Abbott, M. R.: Phytoplankton chlorophyll distributions and primary production in the Southern Ocean, J. Geophys. Res., 105, 28709-28722, doi:10.1029/1999JC000043, 2000.

Moore, J. K. and Doney, S. C.: Remote sensing observations of ocean physical and biological properties in the region of the Southern Ocean Iron Experiment (SOFeX), J. Geophys. Res., 111, C06026, doi:10.1029/2005JC003289, 2006.

Neori, A. and Holm-Hansen, O.: Effect of temperature on rate of photosynthesis in Antarctic phytoplankton, Polar Biol., 1, 33-38, 1982.

Nowlin, W. D. and Klinck, J. M.: The Physics of the Antarctic Circumpolar Current, Rev. Geophys., 24, 469-491, doi:10.1029/RG024i003p00469, 1986.

Odate, T. and Fukuchi, M.: Distribution and community structure of picophytoplankton in the Southern Ocean during the late austral summer of 1992, Proc. NIPR Symp. Polar Biol., 8, 86-100, 1995.

Orsi, A. H., Whitworth III, T., and Nowlin, W. D.: On the meridional extent and fronts of the Antarctic Circumpolar Current, Deep-Sea Res. Pt. I, 42, 641-673, 1995.

Pollard, R. T., Lucas, M. I., and Read, J. F.: Physical controls on biogeochemical zonation in the Southern Ocean, Deep-Sea Res. Pt. II, 49, 3289-3305, 2002.

Read, J. F., Lucas, M. I., Holley, S. E., and Pollard, R. T.: Phytoplankton, nutrients and hydrography in the frontal zone between the Southwest Indian Subtropical gyre and the Southern Ocean, Deep-Sea Res. Pt. I, 47, 2341-2368, 2000.

Rintoul, S. R. and Bullister, J. L.: A late winter hydrographic section from Tasmania to Antarctica, Deep-Sea Res. Pt. I, 46, $1417-$ $1454,1999$.
Sarmiento, J. L., Gruber, N., Brzezinski, M. A., and Dunne, J. P.: High-latitude controls of thermocline nutrients and low latitude biological productivity, Nature, 427, 56-60, 2004.

Seeyave, S., Lucas., M. I., Moore, C. M., and Poulton, A. J.: Phytoplankton productivity and community structure in the vicinity of the Crozet Plateau during austral summer 2004/2005, Deep-Sea Res. Pt. II, 54, 2020-2044, 2007.

Smith, W. O. and Comiso, J. C.: Influence of sea ice on primary production in the Southern Ocean: A satellite perspective. J. Geophys. Res., 113, C05S93, doi:10.1029/2007JC004251, 2008.

Smith, R. C., Baker, K. S., Dierssen, H. M., Stammerjohn, S. E., and Vernet, M.: Variability of primary production in an Antarctic marine ecosystem as estimated using a multi-scale sampling strategy, Am. Zool., 41, 40-56, 2001.

Smith, R. C., Martinson, D. G., Stammerjohn, S. E., Iannuzzi, R. A., and Ireson, K.: Bellingshausen and western Antarctic Peninsula region: Pigment biomass and sea-ice spatial/temporal distributions and interannual variability, Deep-Sea Res. Pt. II, 55, 1949-1963, 2008.

Sokolov, S. and Rintoul, S. R.: Structure of Southern Ocean fronts at $140^{\circ}$ E, J. Marine Syst., 37, 151-184, 2002.

Sokolov, S. and Rintoul, S. R.: Circumpolar structure and distribution of the Antarctic Circumpolar Current fronts: 2. Variability and relationship to sea surface height, J. Geophys. Res., 114, C11019, doi:10.1029/2008JC005248, 2009.

Strathmann, R. R.: Estimating the organic carbon content of phytoplankton from cell volume or plasma volume, Limnol. Oceanogr., 12, 411-418, 1967.

Strutton, P. G., Griffiths, F. B., Waters, R. L., Wright, S. W., and Bindoff, N. L.: Primary productivity off the coast of the East Antarctica (80-150 E): January to March 1996, Deep-Sea Res. Pt. II, 47, 2327-2362, 2000.

Suzuki, K., Kuwata, A., Yoshie, N., Shibata, A., Kawanobe, K., and Saito, H.: Population dynamics of phytoplankton, heterotrophic bacteria, and viruses during the spring bloom in the western subarctic Pacific, Deep-Sea Res. Pt. I, 58, 575-589, 2011.

Takahashi, T., Sutherland, S. C., Sweeney, C., Poisson, A., Metzl, N., Tilbrook, B., Bates, N., Wanninkhof, R., Feely, R. A., Sabine, C., Olafsson, J., and Nojiri, Y.: Global sea-air CO2 flux based on climatological surface ocean $\mathrm{pCO}_{2}$, and seasonal biological and temperature effects, Deep-sea Res. Pt. II, 49, 1601-1622, 2002.

Tomas, C. R.: Identifying Marine Phytoplankton, Academic Press, 858 pp., 1997.

Tomczak, M. and Godfrey, J. S.: Regional oceanography: An introduction, 2nd Edn., Daya Publishing House, 390 pp., 2003.

Tréguer, P. and Pondaven, P.: Silica control of carbon dioxide, Nature, 406, 358-359, 2000.

Trenberth, K. E., Large, W. G., and Olson, J. G.: The mean annual cycle in global ocean wind stress, J. Phys. Oceanogr., 20, 1742 1760, 1990.

Tsuda, A. and Kawaguchi, S.: Microzooplankton grazing in the surface water of the Southern Ocean during an austral summer, Polar Biol., 18, 240-245, 1997.

Uitz, J., Claustre, H., Griffiths, F. B., Ras, J., Garcia, N., and Sandroni, V.: A phytoplankton class-specific primary production model applied to the Kerguelen Islands region (Southern Ocean), Deep-sea Res. Pt. I, 56, 541-560, 2009.

van der Merwe, P., Lannuzel, D., Bowie, A. R., and Meiners, K. M.: High temporal resolution observations of spring fast ice melt and 
seawater iron enrichment in East Antarctica, J. Geophys. Res., 116, G03017, doi:10.1029/2010JG001628, 2011.

Vernet, M., Martinson, D., Iannuzzi, R., Stammerjohn, S., Kozlowski, W., Sines, K., Smith, R., and Garibotti, I.: Primary production within the sea-ice zone west of the Antarctic Peninsula: I - Sea ice, summer mixed layer, and irradiance, Deep-sea Res. Pt. II, 55, 2068-2085, 2008.

Ward, J. H.: Hierarchical grouping to optimize an objective function, J. Am. Stat. Assoc., 58, 236-244, 1963.

Westwood, K. J., Griffiths, F. B., Meiners, K. M., and Williams, G. D.: Primary productivity off the Antarctic coast from $30^{\circ}-80^{\circ} \mathrm{E}$; BROKE-West survey, 2006, Deep-Sea Res. Pt. II, 57, 794-814, 2010.

Wright, S. W. and van den Enden, R. L.: Phytoplankton community structure and stocks in the East Antarctic marginal ice zone (BROKE survey, January-March 1996) determined by CHEMTAX analysis of HPLC pigment signatures, Deep-Sea Res. Pt. II, 47, 2363-2400, 2000.

Wright, S. W., Thomas, D. P., Marchant, H. J., Higgins, H. W., Mackey, M. D., and Mackey, D. J.: Analysis of phytoplankton of the Australian sector of the Southern Ocean: comparisons of microscopy and size frequency data with interpretations of pigment HPLC data using the 'CHEMTAX' matrix factorisation program, Mar. Ecol. -Prog. Ser., 144, 285-298, 1996.
Wright, S. W., Ishikawa, A., Marchant, H. J., Davidson, A. T., van den Enden, R. L., and Nash, V: Composition and significance of picophytoplankton in Antarctic waters, Polar Biol., 32, 797-808, 2009.

Wright, S. W., van den Enden, R. L., Pearce, I., Davidson, A. T. Scott, F. J., and Westwood, K. J.: Phytoplankton community structure and stocks in the Southern Ocean $\left(30^{\circ}-80^{\circ} \mathrm{E}\right)$ determined by CHEMTAX analysis of HPLC pigment signatures, Deep-Sea Res. Pt. II, 57, 758-778, 2010.

Zhang, J.: Increasing Antarctic sea ice under warming atmospheric and oceanic conditions, J. Climate, 2515-2529, 2007.

Zubkov, M. V., Sleigh, M. A., Tarran, G. A., Burkill, P. H., and Leakey, R. J. G.: Picoplanktonic community structure on an Atlantic transect from $50^{\circ} \mathrm{N}$ to $50^{\circ} \mathrm{S}$, Deep-Sea Res. Pt. I, 45, 1339-1355, 1998. 